\title{
Testicular Large Cell Calcifying Sertoli Cell Tumor
}

National Cancer Institute

\section{Source}

National Cancer Institute. Testicular Large Cell Calcifying Sertoli Cell Tumor. NCI

Thesaurus. Code C39944.

A testicular Sertoli cell tumor characterized by the presence of large polyg onal cells with eosinophilic cytoplasm in a myxoid and hyalinized stroma. Calcifications may be present in the stroma. Malignant behavior is uncommon. 